\title{
LEKSYKALIZACJA ZDAŃ ROZWIJAJĄCYCH Z WYRAŻENIAMI COKOLWIEK I CO W FUNKCJI KOMENTARZA METATEKSTOWEGO ${ }^{1}$
}

\section{WPROWADZENIE}

Przedmiotem analizy w poniższym artykule będą konstrukcje $z$ wyrażeniami cokolwiek i co, ilustrowane przez poniższe zdania:

(1) Budżet na przyszły rok zajmowat ich mniej niż ta - co by nie powiedzieć - światopogladowa kwestia [NKJP-PELCRA: „Słowo Polskie Gazeta Wrocławska", 2004].

(2) Pod koniec kwietnia kariera Izabeli Jarugi-Nowackiej w Unii Pracy osiagnęła szczyt. (...) Zdeklarowana feministka nie ukrywa satysfakcji z bycia pierwsza kobieta na czele - czego by nie rzec-znaczacej siły politycznej $w$ kraju [NKJP: „Polityka”, 2004].

(3) Tymczasem każdy z państwa doskonale zdaje sobie sprawę, że wszystko jest ważne. Ważne jest metro, ważne sa wszelkie inne inwestycje. Natomiast dla Ślaska, czegokolwiek by nie powiedzieć, gdy nie będzie wody zdatnej do picia, to wszelkie inne inwestycje sa drugorzędne, wtórne [KDP].

(4) Prawda, że część nastolatków traktowała tę piosenke dość powierzchownie $i$ utylitarnie, jako pretekst do-zaiste! - nieco przedwczesnej nobilitacji całego polskiego „big-beatu”, uginajacego się-cokolwiek by nie powiedzieć o talencie i popularności całej fali „kolorowych" zespołów („Niebiesko-, Zielono- $i$ Czerwono-Czarni”) - pod brzemieniem wtórności [NKJP-PELCRA: R. Radoszewski, Czesław Niemen: kiedy się dziwić przestanę...: monografia artystyczna, 2004].

Wyrażenia takie jak pokazane w przykładach (1)-(4), cechuja się pewnymi powtarzalnymi własnościami. Po pierwsze, w ich skład wchodzi zaimek co lub cokolwiek $\mathrm{w}$ formie biernika lub dopełniacza, przy czym

${ }^{1}$ Badania dokonane $\mathrm{w}$ ramach realizacji projektu finansowanego ze środków Narodowego Centrum Nauki w latach 2015-2020 na podstawie decyzji DEC-2014/14/E/HS2/00281. 
w tekstach mówionych (bądź w wypadku odmiany pisanej - we fragmentach stylizowanych na język mówiony) częściej spotykana jest forma biernikowa, podczas gdy w odmianie pisanej - dopełniaczowa. Drugim charakterystycznym elementem jest w tych konstrukcjach wyrażenie by oraz wykładnik negacji nie, który - zgodnie $z$ zasadami normy językowej - powinien wymusić użycie dopełniacza. Ich prawostronne kolokaty to zwykle czasowniki mówić, powiedzieć i rzec w formach nieosobowych (najczęściej w postaci bezokolicznika), a same wyrażenia co // cokolwiek by nie pozostaja w relacji kookurencji ${ }^{2}$ wobec wypowiedzenia, do którego treści się odnosza. Co ciekawe, zapytanie o układy typu cokolwiek // czegokolwiek by nie_oraz co // czego by nie_z prawostronnymi uzupełnieniami w postaci czasowników mówić, powiedzieć, rzec w bezokoliczniku w próbce korpusu zrównoważonego NKJP daje wyłącznie wyniki $\mathrm{w}$ postaci przykładów, w których wyrażenia te są kookurentne $z$ wypowiedzeniem podstawowym, ${ }^{3}$ nigdy zaś - przykłady, które można by uznać za ilustrację relacji zależności składniowej (jak choćby w zdaniach typu Cokolwiek powie konkurent, będzie źle) [NKJP-PELCRA: „Tygodnik Powszechny”, 1994]. W dalszej części artykułu wyrażenia te zostana poddane analizie zmierzajacej do ustalenia ich dystrybucji, postaci, a także własności semantyczno-składniowych.

\section{STAN BADAŃ}

Kwestie zwiąane $z$ własnościami wyżej pokazanych konstrukcji wpisuja się w szerszą dyskusję na temat zdań względnych i zdań rozwijajacych $z$ jednej strony, $z$ drugiej zaś - procesu leksykalizacji i pragmatykalizacji, rozumianej tak, jak ujmuje to m.in. Laurel J. Brinton [2008]. ${ }^{4} \mathrm{~W}$ polskim językoznawstwie bardzo szeroka, formalną definicję

2 Konsekwentne rozróżnienie składni współwystępowania (kookurencji) i składni zależności leży u podstaw rozpoznań Jadwigi Wajszczuk [1997; 2005], która przypomina, że wzajemna niesprowadzalność obu składni pokazał Andrzej Bogusławski [1977].

3 Używam tego określenia, podobnie jak w książce o parentezie [Stępień 2014], aby uniknać terminu zdanie // wypowiedzenie główne, powszechnie stosowanego w tradycyjnej analizie składniowej. Nie znalazłam lepszego odpowiednika używanego w literaturze anglojęzycznej terminu host sentence.

4 Pragmatykalizacja jest procesem, w wyniku którego jednostka leksykalna $z$ poziomu przedmiotowego ulega przekształceniu w tzw. operator dyskursu (discourse marker) bezpośrednio, $z$ pominięciem fazy gramatykalizacji, rozumianej jako etap pełnienia funkcji szeroko pojmowanego morfemu gramatycznego. W wyniku tego procesu powstają wyrażenia pełniące funkcję wykładników spójności tekstu, operujące na poziomie tekstu, a nie - pojedynczego wypowiedzenia. Dyskusja na temat podobieństw i różnic między procesem gramatykalizacji i pragmatykalizacji, wraz $z$ różnymi stanowiskami, została przedstawiona m.in. przez Brinton [2008, 61-66]. 
zdań względnych (jako wprowadzanych przez zaimki względne i przeciwstawianych zdaniom spójnikowym) bodaj jako pierwszy przyjął Leon Zawadowski [1952]. Zważywszy, że autor Zagadnień teorii zdań względnych nie określa, czym jest zaimek względny, jego definicja jest de facto nieoperacyjna, a sam zaimek względny jako przedmiot badań - trudny do wyodrębnienia, ${ }^{5}$ można przyjąc, że analizowane przeze mnie $z$ dania mieszczą się w kategorii szeroko pojmowanych zdań względnych. L. Zawadowski zwrócił też uwagę na pokrewieństwo zdań względnych nazywanych później przez Zuzannę Topolińską ${ }^{6}$ [1984, 335; 343-349] apozytywnymi $z$ konstrukcjami nawiasowymi, czyli parenteza, wskazujacc, że w układach takich jak Piotr, który jest bardzo roztargniony, znowu zgubit parasol $\mathrm{l}^{7}$ danie $\mathrm{z}$ który można potraktować jak nawiasowe, wtracone i opuścić bez szkody dla interpretacji odniesienia rzeczownika ze zdania nadrzędnego. L. Zawadowski uważa, że takie zdania względne niedystynkcyjne, jak je określa, sa odrębnymi wypowiedzeniami i jako odrębnych wypowiedzeń można ich również użyć. $Z$ problematyką tak pojmowanych zdań względnych łączy analizowane przeze mnie wyrażenia występowanie wyrażeń co i cokolwiek, które moga być uznane za zaimki względne. Zbliża je również fakt, że zdania te można potraktować jak nawiasowe i opuścić. Nie sposób ich jednak użyć jako samodzielnych wypowiedzeń, usuwając wyrażenia co i cokolwiek.

$\mathrm{W}$ ujęciu transformacyjno-generatywnym, przywołanym przez $\mathrm{Zu}$ zannę Topolińska [2001], konektor relatywny (zaimek względny), w najbardziej typowych zdaniach względnych semantycznie pusty, jest zgodny pod względem liczby i rodzaju $z$ tym wyrażeniem zdania matrycowego, które charakteryzuje, pod względem przypadka zaś podlega oddziaływaniu składniowemu orzeczenia (centrum zdaniotwórczego) zdania względnego. Dodatkowo w zdaniach takich zaimek ma swój korelat w postaci odpowiednich form wyrażeń: ten lub taki; korelat wprawdzie nie zawsze zostaje zrealizowany powierzchniowo, ale zawsze jest możliwy do uzupełnienia. Jak widać, ta charakterystyka jest czysto formalna. $Z$. Topolińska wprowadza jednak pewna semantyczna dystynkcje, mianowicie, podobnie jak wcześniej L. Zawadowski [1952] i inni badacze, w tym i ona sama w GWJP, odróżnia zdania służące identyfikacji referenta zdania względnego i odpowiadającego mu wyrażenia w zdaniu matrycowym (inaczej: zdania względne restryktywne) od takich, które nie pełnią funkcji prymarnie referencyjnej (zdania względne apozytywne). Rozróżnienia czynione przez Z. Topolińska sa w kontekście prowadzonych tu rozważań o tyle istotne, że autorka analizuje status dwóch typów zdań z zaimkami

5 W książce L. Zawadowskiego przedmiotem badań są zdania z wyrażeniami który oraz (w znacznie mniejszym stopniu) jaki.

6 Z. Topolińska wprowadziła rozróżnienie atrybucji restryktywnej i apozytywnej oraz odpowiednio konstrukcji względnej restryktywnej i apozytywnej.

7 Przykład podany przez L. Zawadowskiego [1952, 25]. 
kto i co. Jeden $z$ nich to zdania o postaci Kto pyta, (ten) nie bładzi, Kto przybiegnie pierwszy, tego czeka piękna nagroda, Oddaj to, co zabrałeś, w których możliwość uzupełnienia korelatu to lub ten oznacza, że zaimki co i kto można uznać za wbudowane w grupę imienna i pozycję otwartą przez inne wyrażenie zdania matrycowego dla grupy imiennej. Inaczej rzecz się ma w wypadku zdań, w których wspomnianego korelatu nie sposób wprowadzić, jak np. Ania od rana grymasiła, co mnie wyprowadziło $z$ równowagi. ${ }^{8}$ Badaczka interpretuje je jako diatetyczny wariant dwóch innych możliwości: 1 . To, że Ania od rana grymasiła, wyprowadziło mnie $z$ równowagi. Wyprowadziło mnie $z$ równowagi to, że Ania od rana grymasiła. 2. Ania od rana grymasiła. To mnie wyprowadziło $z$ równowagi. O ile drugi wariant (bliski rozwiazaniu proponowanemu przez L. Zawadowskiego) powoduje powstanie dwóch niezależnych zdañ ${ }^{9}$ i tym samym wykracza poza problematykę zdań względnych, o tyle pierwszy - zdaniem autorki, która powtarza tu argumentację Z. Klemensiewicza - stanowi dowód na to, że konstrukcje typu $q$, co $p$ należy uznać za diatetyczne derywaty zdania względnego o postaci to, że $q, p$.

Tropem Z. Topolińskiej podążał prawdopodobnie Andrzej Moroz [2010], uznając zdania typu Ania od rana grymasiła, co mnie wyprowa$d z i ł o ~ z$ równowagi za rezultaty jednego $z$ typów operacji parentetyzujących. Należy przy tym uczciwie zauważyć, że wyrażenia $z$ układami typu co // cokolwiek, nie_ i uzupełnieniem czasownikowym w bezokoliczniku nie sa przez autora analizowane. Przyporzadkowanie przykładów takich jak (1)-(4) do grupy struktur syndetycznych $z$ systemowo przewidywalnym komponentem inicjalnym ${ }^{10}$ jest więc wynikiem mojej interpretacji ujęcia A. Moroza.

O problemie relatywizacji w odniesieniu do zdań z jak, pokrewnych analizowanym przeze mnie konstrukcjom, pisała Jolanta Chojak [2009, 49-59]. Jest to zagadnienie istotne w kontekście prowadzonych tu rozważań, ponieważ - obok zdań takich jak pokazane w przykładach (1)-(4) - w polszczyźnie funkcjonuja pokrewne im struktury o postaci: wyraże-

8 Przykład za Z. Topolińska [2001, 599-600].

9 Alternatywnie może to być również zdanie współrzędnie złożone ze spójnikiem $i$ lub $a$.

10 Badacz dzieli czasownikowe ciagi parentetyczne na asyndetyczne - bez inicjalnego komponentu funkcyjnego w postaci wyrażeń typu jak, o ile, co - oraz syndetyczne, które taki komponent zawieraja [Moroz 2010, 249-250]. Te ostatnie podlegaja podziałowi na takie, w których inicjalne wyrażenie funkcyjne zajmuje pozycję otwarta przez czasownik i w zwiazku $z$ tym jest systemowo przewidywalne, oraz takie, w których wyrażenia inicjalne typu jak, jakby, jeśli, jeżeli, o ile, na ile, że, żeby i in. nie zajmuja pozycji otwieranej przez czasownik. Systemowa przewidywalność jest zdaniem autora widoczna m.in. w przybieraniu przez co form przypadka wynikających $z$ wymagań składniowych czasownika. 
nie homograficzne $z$ zaimkiem względnym lub spójnikiem ${ }^{11}$ (jak // gdzie) + by + nie + czasownik w formie nieosobowej, zwykle $\mathrm{w}$ bezokoliczniku, np.:

(5) Nie jestem na bieżaco, ale średnia płaca to coś koło dwóch tysięcy, tyle że brutto. I dwóch na trzech pracujacych zarabia poniżej średniej. Czyli, jak by nie patrzeć, jesteś finansowa elita [NKJP-PELCRA: A. Baniewicz, Drzymalski przeciw Rzeczpospolitej, 2004].

(6) Syn zamordowanego ministra spraw zagranicznych Orlando Leteliera jest deputowanym socjalistycznym, poprzedni minister spraw zagranicznych, obecnie przedstawiciel Chile w ONZ - Juan Gabriel Valdés jest synem senatora, gdzie nie spojrzeć - rodzina [NKJP-PELCRA: D. Passent, Choroba dyplomatyczna, 2002]. ${ }^{12}$

J. Chojak [2009, 52-58] formułuje w języku składni semantycznej charakterystykę poszczególnych typów zdań względnych opisywanych $\mathrm{w}$ literaturze przedmiotu. Wyróżnia zdania realizujące pozycję argumentu w podstawowym wyrażeniu predykatowo-argumentowym (np. Kto sieje wiatr, (ten) zbiera burze), zdania (restryktywne i apozytywne) dodane do wyrażeń realizujących pozycję argumentu oraz przeciwnie - dodane do wyrażeń nierealizujaccych takiej pozycji, a ponadto - zdania charakteryzujące predykat podstawowy (np. Zrób to tak, jak ci kazałem), zdania stanowiące integralną część predykatu, wreszcie - komentarze metatekstowe w rozumieniu Andrzeja Bogusławskiego [1979], w tym wykładniki równoważności lokucyjnej (Nie był to, jak sądzę, najlepszy pomyst) [zob. Bogusławski 2008] oraz zdania rozwijajace typu Znowu nie doszli do porozumienia, co można było przewidzieć. Analizowane przeze mnie wyrażenia wpisywałyby się w tym ujęciu w kategorię komentarzy metatekstowych, będacych zdaniami względnymi sensu largo.

J. Chojak zwraca uwage także na inny problem, niezwykle ważny w kontekście analizowanych przeze mnie wyrażeń, mianowicie na to, że większość badaczy składni traktuje własności prozodyczne struktur składniowych w sposób marginalny. Tymczasem w wypadku wypowiedzenia rozumianego jako jednostka komunikacji jest to problem kluczowy. Właściwą range nadaje mu Jadwiga Wajszczuk [1997], która proponuje inspirująca interpretację czynnościowej teorii języka J.L. Austina, uznajac akt fonetyczny za spoiwo łączące akt fatyczny (wybór wy-

11 Kwestia liczby jednostek leksykalnych o kształcie jak, a także ich charakterystyki, jest złożona i dyskusyjna [zob. J. Chojak 2009]. W wypadku gdzie sprawa jest tylko trochę łatwiejsza, gdyż z listy możliwości do wyboru odpada przyimek.

12 W przykładach takich jak (6) gdzie nie używane jest wymiennie z gdziekolwiek, a także gdziekolwiek nie. Do możliwości dwojakiej interpretacji wypowiedzeń takich jak (6) odnoszę się w dalszej części tekstu. 
rażenia predykatywnego i jego uzupełnień) i retyczny (uporządkowanie tematyczno-rematyczne), a zatem ostatecznie odpowiadające za to, że mamy do czynienia $z$ aktem komunikacji. Jak zauważa J. Chojak, bez uwzględnienia właściwości prozodycznych, aktualizujaccych się w akcie fonetycznym, nie jesteśmy w stanie prawidłowo wyodrębnić jednostek analizy. Takie podejście nakłada istotne ograniczenia na procedury transformacji składniowych: konstrukcje składniowe - wyjściowa i będąca wynikiem przekształcenia - powinny być równoważne także pod względem charakterystyki prozodycznej. Czy warunek ten spełniaja przekształcenia zaproponowane przez Z. Topolińska [2001], A. Moroza [2010], a $z$ autorów prac wcześniejszych - L. Zawadowskiego [1952]? Czy - i w wypadku których zdań - procedura uzupełniania tzw. korelatu w zdaniu nadrzędnym jest rzeczywiście uprawniona? Sa to kwestie wymagajace dopiero zbadania i rodzace dalsze, dodatkowe trudności, których nie sposób rozwiązać w jednym artykule.

Wprowadzane m.in. przez zaimek co wypowiedzenie rozwijające, które nie uzupełnia zdania nadrzędnego żadnym składnikiem - nie jest więc żadnym $z$ typów wypowiedzenia podrzędnego - Zenon Klemensiewicz [1969, 100] nazwał wypowiedzeniem rozwijaj a cy m (przydopełnieniowym, przypodmiotowym etc). $\mathrm{W}$ analizowanych przeze mnie przykładach należałoby jednak w myśl Klemensiewiczowskich kryteriów widzieć raczej wypowiedzenia z e s t a w i o n e [tamże, s. 104-105]. Podobnie, raczej jako zdania zestawione niż rozwijające, kwalifikować by je należało za Stanisławem Jodłowskim [1976, 195; 209-212].

Jeśli chodzi o opis leksykograficzny, to USJP osobno notuje co m.in. jako zaimek rzeczowny względny, przyłączający do wypowiedzenia nadrzędnego wypowiedzenie podrzędne, a osobno - jako przyłączający wypowiedzenie rozwijające, a także jako wprowadzajacy zwiąki frazeologiczne, takie jak np. co tu dużo mówić. Z kolei cokolwiek to zaimek rzeczowny względny, wprowadzający zdanie o treści 'niezależnie od tego, co; bez względu na to, co', analogicznie ujmuje tę kwestię ISJP.

Osobny problem stanowia kwestie poprawności konstrukcji z zaimkiem cokolwiek i ich odpowiedników $z$ co. W WSPP pod hasłem cokolwiek znajdujemy informację, że zdania typu czego by nie zapragnat sa niepoprawne, podobnie jak zdania typu cokolwiek by nie zrobit. W obu przykładowych kontekstach WSPP wskazuje jako poprawne konstrukcje $z$ samym zaimkiem cokolwiek, ewentualnie $z$ wyrażeniem cokolwiek by (bez nie), np. Cokolwiek by zrobit, czegokolwiek zapragnat. Jest to kwestia istotna $\mathrm{w}$ kontekście wielości wariantów analizowanych $\mathrm{w}$ tym artykule konstrukcji z cokolwiek // co, którymi posługują się użytkownicy współczesnej polszczyzny. $Z$ kontaminacji kalki z języka rosyjskiego (czego by nie / / cokolwiek by nie + czasownik) oraz poprawnej polskiej konstrukcji cokolwiek // cokolwiek by + czasownik powstały obecnie używane warianty tych konstrukcji, opisywane dokładniej w następnych akapitach (bodaj najpowszechniejsze jest wyrażenie co by nie mówić // powiedzieć). 
W SGPP opisana została jednostka $\mathrm{Co}_{-}$jako otwierajacca miejsce walencyjne dla przymiotnika w stopniu równym lub wyższym (USJP i ISJP notuja w tym wypadku frazeologizmy o postaci co więcej, co gorsza), ale nie jako jednostka otwierająca miejsce dla czasownika. $Z$ kolei w opracowaniach rejestrujących różne wyrażenia metatekstowe i opisujących ich funkcje, np. Bralczyk 1978; Ożóg 1990; Piekarczyk 2013, interesujące mnie wyrażenia pojawiaja się jedynie marginalnie, o ile w ogóle występują. Wyrażenie czego // co by o [kimś/ czymś] nie mówić // nie powiedzieć_ było przedmiotem refleksji - obok innych, zawierających formy fleksyjne czasownika mówić / powiedzieć i wykładnika nie - w artykule Magdaleny Danielewiczowej [2018], która uznała je za metatekstową leksykalna jednostkę języka.

$\mathrm{W}$ tym miejscu warto również przyjrzeć się samemu co $\mathrm{w}$ funkcji wskaźnika zespolenia w perspektywie diachronicznej. Już w pracy Stanisława Urbańczyka [1939], a później w Historii składni Krystyny Pisarkowej [1984], odnajdziemy wiele argumentów przemawiających za tym, że w polszczyźnie od dawna istniały różne wykładniki zespolenia o kształcie co: zaimek względny i spójnik, a co spójnikowe wprowadzało różne typy zdań podrzędnych, poza okolicznikowymi warunku i przyzwolenia [Urbańczyk 1939]. Historycznie co było również stosowane w funkcji włącznika [termin Wajszczuk 1997] w zdaniach typu świadczymy, co (dziś: że); już jednak za czasów S. Urbańczyka było ono w tej funkcji używane jedynie w gwarach. Podobnie, co w zdaniach okolicznikowych celu, występujace zawsze $z$ by, np. Wiedzcie o sobie, cobyście nie nawiedzili Koppenhaggen, ${ }^{13}$ od dawna nie jest używane w tej funkcji w polszczyźnie literackiej, choć - jak zaświadcza S. Urbańczyk [1939] - wciąż używane w gwarach. ${ }^{14}$

$\mathrm{Z}$ kolei wyrażenie cokolwiek powstało $\mathrm{z}$ połaczenia co i partykuły -kole, -koli(věk), która ma swoje źródło w zaimku przysłownym *kolě/i 'kiedy, kiedyś', jako morfemu sufiksalnego. $Z$ zaimka tego wykształcił się morfem przez K. Pisarkowa [1984, 231-233] nazywany partykuła (współcześnie należałoby go uznać zapewne za modyfikator deklaratywności), majacy jednocześnie znaczenie uogólniające i nieokreślone. Choć pierwotnie istniały wskaźniki zespolenia $z$ różnymi wariantami tej partykuły, do naszych czasów zachowały się tylko połączenia $z$ ostatnim $z$ nich. ${ }^{15}$

13 Przykład za S. Ubrańczykiem [1939, 45], oryginalnie z Pamiętników J.Ch. Paska.

${ }^{14}$ Co w funkcji spójnika i zaimka względnego, bliskoznacznego który, było systematycznie rugowane przez normatywistów dopiero około lat 30. XX w., jednak niemal do końca XIX w. było w tych funkcjach zalecane [por. Pisarkowa 1984, 235 - o tym zjawisku oraz o jego możliwych przyczynach].

15 Dziękuję Recenzentowi za zwrócenie mi uwagi na to, że proces powstania wyrażeń typu cokolwiek i wykształcania się ich funkcji przebiegał jednak nieco odmiennie od tego, jak przedstawiła to K. Pisarkowa [1984]. Zauważył on, że morfem -kole, -koli(věk) należałoby traktować raczej jako modyfikator deklara- 
Jak zauważa K. Pisarkowa, ta uogólniona nieokreśloność morfemu -kolwiek odpowiedzialna jest za komponent warunkowy zdań ze wskaźnikami zespolenia, które go zawieraja, w tym ze wskaźnikiem cokolwiek. $Z$ tej własności m.in. wynika też przytoczona powyżej interpretacja zdań o postaci czego by nie zapragnat czy cokolwiek by nie zrobił jako niepoprawnych, zawarta choćby we wspomnianym WSPP.

\section{POSTAĆ WYRAŻEŃ I ICH DYSTRYBUCJA}

Układy z wyrażeniami co i cokolwiek - oprócz własności wymienionych we wprowadzeniu - cechuje także trzecia, zdecydowanie mniej oczywista, mianowicie możliwość użycia zarówno w wariancie $z$ wyrażeniem nie, jak i bez tego wyrażenia, por.:

(7) - Co bedzie? - wzruszyła ramionami Kasia. - To samo, co z pozostała piatka. Urodzę. A zreszta, jedynaki źle się chowaja - spojrzała zaczepnie w moja stronę. - Cokolwiek by mówić, moja kochana, twoje dzieci jedynakami nigdy nie były - zwróciła jej uwage babcia [NKJP-PELCRA: G. Plebanek, Pudełko ze szpilkami, 2002].

Co więcej, samo nie można elidować - por. (4a) lub dodawać - por. (7a) bez zmiany funkcji całego wyrażenia. W wypadku układów typu cokolwiek by nie_ i cokolwiek by_ ${ }^{16}$ oba warianty występuja we wszystkich typach tekstów $\mathrm{i}$ - dla połączeń z czasownikiem mówić // powiedzieć - maja podobną częstotliwość:

(4a) Część nastolatków traktowała te piosenkę (...) jako pretekst do nieco przedwczesnej nobilitacji całego polskiego „big-beatu”, uginajacego się-cokolwiek by powiedzieć o talencie i popularności całej fali „kolorowych" zespołów - pod brzemieniem wtórności.

(7a) Cokolwiek by nie mówić, moja kochana, twoje dzieci jedynakami nigdy nie byty - zwróciła jej uwage babcia.

Watpliwości może budzić układ z co by bez nie. Jest on zdecydowanie rzadszy (pojedyncze wystapienia w przeszukiwanych korpusach) i ogra-

tywności, a jego funkcja uogólniająca (później także nieokreślona) wykształciła się zapewne $z$ funkcji pytajnej. Recenzent zastrzegł również, że jest wątpliwe, aby funkcja warunkowa wykształciła się ze znaczenia odpowiadającego za nieokreśloność czy uogólnianie odniesienia. Jak sam jednak zauważył, rozstrzygnięcie tego problemu wymaga dalszych badań. Ponieważ nie było to celem artykułu, w tym punkcie poprzestaję więc na odniesieniu się do ustaleń K. Pisarkowej, nie wchodząc $z$ jej stanowiskiem w głębszą dyskusję.

16 Z których pierwszy $z$ punktu widzenia normy językowej należy uznać za niepoprawny. 
niczony w zasadzie do mówionej odmiany języka (wraz ze wspomnianymi stylizacjami na odmianę mówiona, spotykanymi powszechnie w tekstach pisanych), np.:

(8) Zważcie Państwo, jakim skromnym człowiekiem był ten cenzor. Pozostał $w$ cieniu. A przecież, co by powiedzieć, stał się współautorem tego przeboju [NKJP-PELCRA: „Gazeta Wyborcza”, 1998].

(9) Co by mówić, ci ludzie ciężko pracuja, żeby przetrwać [NKJP-PELCRA: „Express Ilustrowany”, 2003].

Nie zmienia to jednak faktu, że i w tym wypadku oba warianty ( $\mathrm{z}$ nie oraz bez nie) sa używane, a obecność nie lub jego brak nie powoduje zmiany znaczenia całej konstrukcji.

Wyrażenia czegokolwiek // cokolwiek by nie_ oraz cokolwiek by_ w układach takich jak pokazane powyżej pozostaja w dystrybucji identycznej, podobnie jak wyrażenia czego // co by nie,, i co by_, analogicznie do innych układów $z$ nie, jak choćby opodal i nie opodal, wskazane przez Macieja Grochowskiego [2000], a przeciwnie do wyrażeń (że)by_ i (że)by nie_oraz $\dot{z} e_{-}$i $\dot{z} e$ nie, których dystrybucja jest komplementarna [Stępień 2018].

Nad tą właściwościa, polegająca na wyjęciu co // cokolwiek poza zakres oddziaływania wyrażenia nie, którego pojawienie się powinno wymuszać wybór wariantu dopełniaczowego, warto zatrzymać się dłużej. Oczywiście, można zjawisko to postrzegać w kategoriach normy językowej - podobnie jak użycie wyrażenia co w funkcji z punktu widzenia normy językowej zarezerwowanej dla cokolwiek - na tej podstawie uznać za nienormatywne i wykluczyć przykłady $\mathrm{z}$ forma co // cokolwiek w układach z nie. Można jednak również spojrzeć na nie jako na znak postępującej zmiany językowej i interpretować jako sygnał tego, że wyrażenie co stopniowo się usamodzielnia i jest używane podobnie jak że czy żeby w wyrażeniach że tak to ujmę czy by nie powiedzieć dosadniej; przestaje więc być systemowo przewidywalne jako wypełnienie pozycji otwieranej przez czasownik.

Warto w tym miejscu przypomnieć stanowisko Romana Laskowskiego [1991], który sprzeciwia się składniowej tradycji ujmującej co w zdaniach względnych jako nieodmienny zaimek względny. Badacz uznaje, że skoro leksem ten jest pozbawiony właściwości zaimka względnego (nie można go scharakteryzować za pomoca żadnej nominalnej kategorii gramatycznej, klasyfikującej czy fleksyjnej, nie jest też tzw. częścią zdania), a jednocześnie wskazuje relacje między zdaniami składnikowymi wypowiedzenia złożonego bądź między członem jednego zdania składnikowego a drugim zdaniem składnikowym, to takie co należy uznać za „spójnik względny”. Jest to stanowisko przeciwstawne do prezentowanego przez A. Moroza [2010], a - jak się wydaje - znajdujacce uzasadnienie także w zgromadzonym przeze mnie materiale językowym, o czym dalej będzie mowa. Automatyczne potraktowanie co oraz cokolwiek w analizowanych układach 
jako wyrażenia wchodzącego na pozycję otwierana przez czasownik nie jest więc ani interpretacją jedyna możliwa, ani nawet najbardziej uprawniona.

Idąc dalej tropem analizy dystrybucji i substytucji, należy zwrócić również uwagę na fakt, że choć wyrażenia co i cokolwiek są wzajemnie zastępowalne, i to zarówno w układach $z$ nie, jak i bez:

(8a) A przecież, cokolwiek by powiedzieć // cokolwiek by nie powiedzieć, stał się współautorem tego przeboju.

(7b) - Co by nie mówić // co by mówić, moja kochana, twoje dzieci jedynakami nigdy nie były - zwróciła jej uwagę babcia,

to jednak dzieli je pewna zasadnicza różnica, mianowicie o ile $c o \mathrm{w}$ analizowanych układach nie występuje nigdy bez by, o tyle w wypadku cokolwiek jest to możliwe:

(10) A jednak życie i ewolucja stanowia wielkie wyzwanie dla entropii. Cokolwiek powiedzieć o ewolucji, jej istota nie jest $z$ pewnościa wzrost nieuporzadkowania [NKJP-PELCRA: M. Ryszkiewicz, Przepis na człowieka, 1996].

(11) Cokolwiek nie mówić o intelekcie i osobowości tej dziewczyny, ładna była bez dwóch zdań [NKJP-PELCRA: A. Baniewicz, Afrykanka, 2005].

W kontekście przywołanych wcześniej historycznych uwarunkowań wyrażenia cokolwiek wariantywność by w tych układach staje się zrozumiała. Warunkowość zawarta jest już w morfemie -kolwiek, dodawanie by w samej tej funkcji wprowadza więc redundancję (co prawda, rzadko powstrzymuje to użytkowników języka przed takim zabiegiem).

$\mathrm{W}$ ostatecznym rozrachunku mamy zatem do czynienia $z$ dwoma typami konstrukcji:

- co by (nie)_ // czego by nie

- czegokolwiek (by) nie_// cokolwiek (by) (nie),,

gdzie po obu stronach znaku "//" umieszczone zostały wyrażenia wzajemnie zastępowalne, a w nawiasie - segmenty, które moga zostać opuszczone (przy czym opuszczenie nie wyklucza użycia wariantu $z$ postacia dopełniaczowa czego // czegokolwiek, a jego pozostawienie - nie implikuje automatycznie postaci dopełniaczowej). Spośród pozostałych zaimków tworzących również zdania względne podobnie zachowują się następujace pary: ${ }^{17}$

- gdzie (by) (nie),

- gdziekolwiek (by) (nie),

$17 \mathrm{Z}$ wykluczeniem kwestii związanych $\mathrm{z}$ kategoria przypadka. W wypadku tych wyrażeń nie pojawia się również segment by. 


\section{oraz}

\section{- jak (by) nie \\ - jakkolwiek (by) (nie)}

Z oczywistych powodów w wypadku gdzie, gdziekolwiek, jak i jakkolwiek nie ma mowy o wariantywności formy uwarunkowanej kategoria przypadka. $Z$ układami zawierajacymi co oraz cokolwiek łączy je $z$ kolei to, że sa używane w połączeniu $z$ segmentami by i nie, kwestia fakultatywności / obligatoryjności tych elementów jest tu jednak bardziej złożona. Inaczej niż w wypadku układów z co i cokolwiek wygląda też łączliwość - konstrukcje z gdzie // gdziekolwiek wyraźnie preferuja połączenia $z$ czasownikami percepcji wzrokowej (głównie spojrzeć, popatrzeć, obejrzeć się), w wypadku jak // jakkolwiek obok patrzeć częste sa także połączenia $z$ widzieć, interpretować czy rozumieć. Watek ten - choć ciekawy - nie będzie jednak dalej rozwijany.

\section{MOŻLIWE WYPEENIENIA I ŁĄCZLIWOŚĆ}

Z analizy korpusowej czasowników występujacych w układach, które zostały powyżej wyróżnione, wynikają dwa zasadnicze wnioski:

1. sa to podstawowe czasowniki mówienia ${ }^{18}$ sensu stricto: mówić, że, powiedzieć, że_, rzec, $\dot{z} e_{-}-z$ możliwością ewentualnego rozszerzenia tej klasy o pisać //napisać, że_, odnoszące się do mówienia na zasadzie metonimii, ${ }^{19}$ a także podstawowe czasowniki sądu: ${ }^{20}$ myśleć, $\dot{z} e_{-}$, sadzić, $\dot{z} e_{-} ;^{21}$

2. forma fleksyjna uzupełnień czasownikowych jest ściśle określona - jest to forma nieosobowa lub (choć bardzo rzadko) forma osobowa użyta w funkcji nieosobowej [por. Topolińska 1967], np. co by nie mówić, co by się nie mówiło // powiedziało, co by nie powiedzieć, co by nie mówili ( $\mathrm{z}$ forma 3. os. lm. użytej w funkcji nieosobowej).

Liczebność klasy czasowników występujących w analizowanych tu układach mogłaby być - obok kwestii zależności składniowej co i cokolwiek - jednym $z$ głównych zarzutów przeciwko interpretacji analizowanych wyrażeń jako leksykalnych jednostek języka w rozumieniu A. Bogusławskiego [1978; 1988 i in.]. Argument ten jednak można zbić,

18 Przez podstawowe czasowniki mówienia rozumiem takie leksykalne jednostki czasownikowe, których znaczenia nie można rozłożyć na komponenty semantycznie prostsze, $z$ których co najmniej jeden nazywałby akt mowy.

${ }_{19} \mathrm{~W}$ jej rozszerzającym ujęciu, o którym mówi m.in. A. Bogusławski (wykłady w Katedrze Lingwistyki Formalnej UW w latach 2019-2020). Przykłady $z$ pisać // napisać występuja jednak incydentalnie.

20 Sa to czasowniki orzekające, że ktoś jest gotów powiedzieć coś o czymś, choć nie jest tak, że wie, że jest tak, a nie inaczej.

$21 \mathrm{Z}$ zastrzeżeniem, że ich użycie - podobnie jak w wypadku pisać // napisać - jest w porównaniu $z$ czasownikami mówienia incydentalne. 
sięgając do definicji klasy otwartej: klasy wyrażeń złożonych o charakterze otwartym to tylko takie klasy, które „można przedłużać w sposób ograniczony co najwyżej przez przysługująca składnikom tych wyrażeń cechę ogólna, nie można zaś podać ich w postaci wyliczenia" [Bogusławski 1987, 20]. Przy tym

należy się wystrzegać ulegania sugestii małych liczb, sugestii podsuwanej przez okoliczność, że jakieś wyrażenie FAKTYCZNIE występuje w nielicznych, czy nawet dających się spisać w jednej linijce, połączeniach [tamże, s. 31].

Klasa podstawowych czasowników mówienia obejmuje we współczesnej polszczyźnie trzy jednostki: [ktoś] mówi, że_, [ktoś] powiedział, że_ i [ktoś] rzekt, że, oraz czwarta dla odmiany pisanej: [ktoś] pisat // napisat, że, a klasa predykatów sądu - dwie jednostki: [ktoś] sądzi, że_ i [ktoś] myśli, $\dot{z} e_{-},{ }^{22}$ por.:

(12) Jałta, cokolwiek by o niej nie myśleć, stanowiła dla Europy drugiej połowy XX stulecia to samo mniej więcej, czym dla wieku XIX było Swięte Przymierze [NKJP-PELCRA: T.K. Toeplitz, Mój wybór: rzeczy mniejsze, 1998].

W tym kontekście można podstawić każdy z wymienionych wyżej czasowników, włączając sądzić; można również usunąc frazę wskazującą na temat wewnatrzzdaniowy [termin za Z. Zaron 2009, 54]:

(12a) Jałta, cokolwiek by nie sądzić stanowiła dla Europy drugiej połowy XX stulecia to samo mniej więcej, czym dla wieku XIX było Sivięte Przymierze,

a także zastapić ją frazą $z$ zaimkiem to:

(12b) Jałta, cokolwiek by o tym nie sadzić, stanowiła dla Europy drugiej połowy XX stulecia to samo mniej więcej, czym dla wieku XIX było Swięte Przymierze.

Jak zauważa m.in. Barbara Citko [2016], niezintegrowane ${ }^{23}$ zdania apozytywne $z$ zaimkiem co mogą odnosić się do frazy czasownikowej

22 Analogicznie funkcjonuja wyrażenia gdzie nie i gdziekolwiek nie, które występują w układach $z$ podstawowymi czasownikami percepcji wzrokowej: $p a-$ trzeć, popatrzeć, spojrzeć.

23 Termin ten odpowiada zdaniom rozwijajacym lub wybranym zdaniom względnym apozytywnym, w których nie sposób uzupełnić korelatu. Podział na zintegrowane i niezintegrowane zdania apozytywne wprowadził Guglielmo Cinque [2008] na przykładzie włoskich zdań apozytywnych wprowadzanych przez che/cui- (zintegrowane) oraz il quale (niezintegrowane). 
wypowiedzenia podstawowego lub do całego wypowiedzenia, w przeciwieństwie do zdań rozwijających z który, zawsze określających frazę nominalną. Analizowane przeze mnie wyrażenia:

a) moga zawierać frazę wskazująca na temat, do którego się odnoszą (por. np. (4): cokolwiek by nie powiedzieć o talencie i popularności);

b) moga być zredukowane do postaci $z$ samym kolokatem czasownikowym (por. (1)-(3), (7)).

W tym drugim wypadku moga się odnosić do całości lub części wypowiedzenia podstawowego, ale moga również - tak jak w przykładzie (7) - odnosić się do przedtekstu w poprzedzającej replice w dialogu (tu: cokolwiek by mówić o twoich dzieciach / / na temat, o którym rozmawiamy). $\mathrm{W}$ wariancie (a) temat, o którym mowa, zostaje wskazany za pomoca frazy nominalnej w zdaniu $z$ cokolwiek, a w wariancie (b) jest kwestia wnioskowania pragmatycznego opartego na implikaturze konwersacyjnej ('cokolwiek by mówić o tym, o czym mowa'). Można tu też za Z. Topolińską [1984, 326-329] widzieć tzw. zerową anaforę - nieobecność wyrażenia anaforycznego jest gramatycznie i semantycznie w pełni uprawniona, ponieważ zarówno nadawca, jak i odbiorca wiedza, o czym mowa. ${ }^{24}$

Inaczej niż w wypadku zdań $z$ wyrażeniem któr-to, opisywanych przez Jadwige Linde [2019], w analizowanych przeze mnie układach rzeczownik ze zdania względnego nie może być powtórzeniem rzeczownika $z$ wypowiedzenia podstawowego; niemożliwa jest zatem anaforyzacja polegająca na pełnej lub częściowej replice grupy anaforyzowanej; każdorazowo konieczne jest sięgnięcie po odpowiedni zaimek, por. np.:

(10a) A jednak życie i ewolucja stanowia wielkie wyzwanie dla entropii. Cokolwiek powiedzieć o ewolucji, jej istota nie jest $z$ pewnościa wzrost nieuporzadkowania.

Możliwe jest również wprowadzenie do zdania względnego frazy zaimkowej odnoszącej się do wypowiedzenia podstawowego poprzez mechanizm katafory, np.:

(1a) Budżet na przyszły rok zajmowat ich mniej niż ta - co by o niej // o tym nie powiedzieć - światopogladowa kwestia.

Przykłady (10) i (10a) oraz (1) i (1a) pokazują, że zjawisko koreferencji może przebiegać w dwóch przeciwstawnych kierunkach:

a) fraza rzeczownikowa odsyłająca do tego, o czym mowa, znajduje się w wypowiedzeniu podstawowym (referencja), a anaforyczna fraza za-

24 To, że tzw. anafora zerowa jest zjawiskiem regularnym w wyrażeniach metatekstowych zawierających formę czasownikową, pozwala wysunąc hipotezę, że można ten rodzaj anafory rozpatrywać również w kategoriach implikatury konwencjonalnej, rozumianej tak, jak proponuje to Christopher Potts [2002; 2005]. 
imkowa // rzeczownikowa w zdaniu względnym (koreferencja i mechanizm nawiazania wewnątrztekstowego);

b) referencja do tematu wypowiedzi (fraza odsyłajaca do tego, o czym mowa) znajduje się w zdaniu względnym, a w wypowiedzeniu podstawowym - wyrażenie anaforyczne odsyłające do wyrażenia ze zdania względnego (koreferencja i mechanizm nawiązania wewnątrztekstowego).

Podobnie jak w zdaniach z któr- to opisywanych przez J. Linde [2019] możliwa jest również anaforyzacja polegająca na powtórzeniu części frazy nominalnej $z$ wypowiedzenia podstawowego $\mathrm{w}$ zdaniu względnym lub też na użyciu jej parafrazy, np. (10a) powyżej czy (7a):

(7a) - Cokolwiek by o twym potomstwie mówić, moja kochana, twoje dzieci jedynakami nigdy nie były - zwróciła jej uwage babcia.

Nie jest to jednak konieczne i każde $z$ analizowanych przeze mnie zdań można również sprowadzić do następującej postaci:

(10b) Cokolwiek by powiedzieć, istota ewolucji nie jest $z$ pewnościa wzrost nieuporzadkowania,

co $z$ kolei niemożliwe jest w wypadku zdań analizowanych przez J. Linde. W wariancie takim jak (10b) w zdaniu względnym nie ma żadnego wyrażenia referencyjnego, odnoszacego się do tematu wypowiedzi, jest on bowiem wskazany na mocy zerowego wykładnika odniesienia anaforycznego: cokolwiek by powiedzieć [o tym, o czym mowa; ty i ja wiemy, o czym mowa]. Zadaniem odbiorcy jest w takim wypadku identyfikacja tematu oparta na mechanizmie wnioskowania pragmatycznego. Pojawienie się ewentualnych rozwinięć zdania względnego o frazy rzeczownikowe w gruncie rzeczy niewiele wnosi do interpretacji tekstu, nie pomaga dodatkowo odbiorcy w jego dekodowaniu. O tym, że samo wprowadzenie frazy zaimkowej niewiele zmienia, świadczą choćby przykłady takie jak (3), gdzie nawet znając szerszy kontekst, trudno jest określić, do czego należy odnieść wyrażenie czegokolwiek by (o tym) nie powiedzieć.

Na zakończenie tej części rozważań należy dodać, że wprowadzona do układów co by (nie)_ // czego by nie_ oraz czegokolwiek (by) nie // cokolwiek (by) (nie)_ frazę wskazująca na temat wypowiedzi można składniowo zinterpretować jako realizacje miejsca dla tematu wewnątrzzdaniowego otwieranego przez czasownik będacy prawostronnym kolokatem analizowanych wyrażeń.

Badając strukturę wypowiedzeń $z$ analizowanymi wyrażeniami, należy zwrócić uwage na jeszcze jeden element, mianowicie możliwość wprowadzenia w wypowiedzeniu podstawowym korelatu to. Można tu zaobserwować pewną zależność: jeśli (a) wyrażenie metatekstowe ogranicza się do sekwencji co // cokolwiek + by + nie + czasownik i (b) znaj- 
duje się w interpozycji względem wypowiedzenia podstawowego - tak jak choćby w przykładach (1)-(3) - wprowadzenie korelatu to staje się niemożliwe. Gdy jednak wyrażenie zostanie użyte w pozycji inicjalnej - tak jak w (10b), (7) czy (9) - zabieg ten jest dopuszczalny, a w wypadku wyrażeń ze zrealizowana pozycją tematu wewnątrzzdaniowego - całkowicie akceptowalny: ${ }^{25}$

(10c) Cokolwiek powiedzieć o ewolucji, to jej istota nie jest z pewnościa wzrost nieuporzadkowania.

(10d) Cokolwiek by powiedzieć, to istota ewolucji nie jest $z$ pewnościa wzrost nieuporzadkowania.

Jeśli rozpatrujemy te zdania wyłącznie w postaci pisanej, zmiana ta nie pociaga za soba większych perturbacji. W mowie wpłynie jednak na sposób opracowania intonacyjnego całej wypowiedzi - analogicznie jak w wypadku rozróżnienia zdań z jak niewymiennym na tak jak i zdań z jak wymiennym na tak jak [Bogusławski 2008]. W tym wypadku dodanie to automatycznie wymusza opracowanie prozodyczne ze struktura intonacyjną rosnąco-opadająca niezupełną, typowa dla zjawiska progrediencji na granicy zdań składnikowych zdania złożonego. Tymczasem frazy z co i cokolwiek w funkcji komentarza metatekstowego mają intonację wyraźnie rosnąca, ${ }^{26}$ o czym mowa będzie także w dalszej części artykułu. Ze względu na własności pisanej odmiany języka w piśmie struktury te sa więc potencjalnie dwufunkcyjne, w mowie taka dwufunkcyjność nie jest możliwa, gdyż o ich interpretacji zawsze rozstrzyga opracowanie prozodyczne.

\section{SZYK, PROZODIA I WEASNOŚCI SEMANTYCZNE}

W ostatniej $z$ analitycznych części artykułu przyjrzymy się składni omawianych $\mathrm{w}$ nim wyrażeń, rozumianej jako ich zewnętrzne i wewnętrzne uporządkowanie linearne, ich własnościom prozodycznym i funkcji w strukturze tematyczno-rematycznej wypowiedzenia, by następnie przybliżyć ich semantykę.

25 Tę samą prawidłowość możemy zaobserwować w wypadku wyrażenia jak (by) nie_, jakkolwiek (by) (nie)_, ale już nie w wypadku gdzie (by) (nie), gdziekolwiek (by) (nie)_, które nie występują w interpozycji.

26 Te same własności prozodyczne mają wyrażenia jak (by) nie_, jakkolwiek (by) (nie)_, gdzie (by) (nie), gdziekolwiek (by) (nie)_, jednak tylko ciagi z jak i jakkolwiek sa używane w interpozycji, czyli w takim wariancie szyku, który wyklucza wprowadzenie korelatu do wypowiedzenia gospodarza. W wypadku wyrażeń z gdzie // gdziekolwiek jedyną własnością pozwalająca odróżnić zdania podrzędnie złożone $z$ tymi zaimkami od komentarzy metatekstowych jest opracowanie prozodyczne. 
Wewnętrzne uporzadkowanie analizowanych wyrażeń charakteryzuje sie pewna swoboda, ale tylko w obrębie sekwencji składajaccej się $z$ czasownika i frazy wskazujaccej na temat. Uporządkowanie inicjalnych wyrażeń, tj. co // cokolwiek, by oraz wykładnika negacji nie, jest niezmienne: zawsze występują one w kolejności, w jakiej zostały wymienione powyżej. Jeśli pozycja symbolizowana przez „_" zostanie wypełniona przez sam czasownik, wówczas szyk wewnętrzny jest stały. Jeżeli jednak otwierana przez czasownik pozycja dla tematu wewnatrzzdaniowego zostanie $\mathrm{w}$ wypowiedzeniu zrealizowana, możliwa jest zmiana szyku, polegająca na zamianie miejscami formy czasownikowej i frazy wskazującej temat (przy czym nie zawsze bezpośrednio poprzedza czasownik). Jeśli pozycja tematu zostanie zrealizowana za pomoca wyrażenia przyimkowego z samym zaimkiem wskazującym, dopuszczalny jest wyłącznie szyk: fraza wskazujacca temat - czasownik (np. (11), z ewentualnym wykładnikiem negacji nie bezpośrednio przed czasownikiem). W wypadku, gdy pozycja tematu zrealizowana jest przez pełnoznaczny rzeczownik, nadal "domyślny” pozostaje wariant z postpozycją czasownika, ale zamiana uporządkowania na kolejność: czasownik - fraza wskazująca temat również jest dopuszczalna. Jak się wydaje, im dłuższe jest wyrażenie zajmujące pozycję tematu, tym większe prawdopodobieństwo, że znajdzie się ono na końcu całej sekwencji.

Jeśli chodzi o szyk zewnętrzny, to analizowane wyrażenia ciążą ku pozycji inicjalnej w wypowiedzeniu oraz ku interpozycji. Co do pozycji końcowej, wyrażenia $z$ samym uzupełnieniem czasownikowym w tej pozycji nie występuja, wyjąwszy przykłady takie jak (13), w których tworzą intonacyjnie samodzielna jednostkę wypowiedzeniową i są używane $\mathrm{w}$ funkcji emfatycznego dopowiedzenia lub wyrażenia $z$ rosnaca intonacją i zawieszeniem głosu, oddawanym w piśmie za pomocą wielokropka:

(13) Otóż jako uczeń wtedy, nie pamiętam dokładnie 3-4 klasy, przeżyłem autentyczne prześladowania religijne! Żyć nie dawano. $W$ wyciszeniu napięć $i w$ uspokojeniu tej niepotrzebnej, zwłaszcza dla nas, dzieciaków, sytuacji, pomógł nam sam proboszcz (...) A w piątej klasie w ogóle Fałkowo opuściliśmy na zawsze. Ale prześladowania religijne przeżyłem, co by nie powiedzieć! [NKJP-PELCRA: J. Banaszak, Czas nie przeszedł obok, 2008].

Analizowane wyrażenia mają też charakterystyczna, stała intonację - jest ona zawsze rosnąca, nawet jeśli zostaja one wtrącone w strukturę wypowiedzenia podstawowego, tak jak miało to miejsce w przykładach (5), (6) czy (11), także wtedy, gdy dane wyrażenie zostanie użyte w pozycji końcowej, tak jak w przykładzie (13). Od wypowiedzenia podstawowego moga zostać oddzielone pauzami, ale nie jest to konieczne - w wypadku szybkiego tempa wypowiedzi jako prozodyczny sygnał granicy frazy wystarczyć musi sama zmiana przebiegu intonacji. Informacja ta jest 
istotna, gdyż - jak była już o tym mowa - często to prozodia jest podstawowym elementem pozwalającym zdecydować, czy mamy do czynienia ze zdaniem podrzędnie złożonym, czy też $z$ wypowiedzeniem zawierającym wyrażenia analizowane w tym artykule. Opracowanie prozodyczne - obok uporządkowania linearnego - jest również tym, co pozwala określić funkcję wyrażeń w strukturze tematyczno-rematycznej wypowiedzi.

Jeśli chodzi o pozycję analizowanych wyrażeń względem struktury tematyczno-rematycznej wypowiedzenia podstawowego, to albo stoja one przy wyrażeniu pełniącym funkcję dictum tematycznego (np. (7), (10)), albo pomiędzy nośnikiem dictum tematycznego i eksponentem rematu (np. (1), (9) czy (1)), nigdy jednak po wyrażeniu rematycznym. Niezależnie od tego, czy fraza zajmująca pozycję tematu wewnątrzzdaniowego zostanie w analizowanych wyrażeniach użyta czy też nie, tematem, do którego się odnosza, zawsze jest coś, co zostało powiedziane lub jest właśnie mówione - a więc zawsze jest to jakieś wypowiedzenie lub jego część. Jako takie sa więc wyrażeniami dotematycznymi, czyli wprowadzającymi temat wypowiedzi. Temat ten może być zlokalizowany zarówno w wypowiedzeniu, w którym umieszczone zostało wyrażenie co by (nie)_ // czego by nie_ lub czegokolwiek (by) nie_// cokolwiek (by) (nie)_, jak i poza nim - w wypowiedzeniu bezpośrednio je poprzedzającym lub w poprzedzającej replice $\mathrm{w}$ dialogu. $\mathrm{W}$ takim wypadku wyrażenie to - zgodnie $z$ mechanizmem anafory i koreferencji, opisanym przez Z . Topolińska [1984] - pełni również funkcję wykładnika spójności wewnątrztekstowej i spina te dwa wypowiedzenia klamra tematyczną.

Z semantycznego punktu widzenia nie ma powodów, aby traktować omawiane wyrażenia jako dwie odrębne jednostki, gdyż ich znaczenie jest tożsame i opiera się na dwóch komponentach: (a) wskazaniu sądu $p$ zawartego w remacie wypowiedzenia podstawowego, (b) przeciwstawieniu sadu $p$ zawartego $\mathrm{w}$ remacie wypowiedzenia podstawowego tym wszystkim sądom reprezentowanym przez $\sim$ p, które ktoś jest gotów wypowiedzieć na dany temat i które na mocy milczacego, pragmatycznego porozumienia między nadawca a odbiorca sa przyjmowane jako znane obu uczestnikom aktu mowy.

\section{PODSUMOWANIE: STATUS ANALIZOWANYCH WYRAŻEŃ}

Pozostaje rozstrzygnać kwestię ostatnią, mianowicie sprawę statusu analizowanych wyrażeń w języku. Czy sa już one jednostką leksykalna, produktem procesu leksykalizacji czy też pragmatykalizacji, zależnie od przyjętego rozumienia tych pojęć, a jeśli tak, to czy jest to jednostka otwierajaca miejsce składniowe dla odpowiednio scharakteryzowanego semantycznie czasownika, czy też jednostka wielosegmentowa $z$ wariantywnością elementu czasownikowego. Droga leksykalizacji poszła m.in. L. Brinton [2008, 73-110], twierdzac w odniesieniu do an- 
gielskich comment clauses, takich jak that is to say, as you say, że uległy one dekategoryzacji - od swobodnie tworzonych zdań, obejmujacych różne uzupełnienia pozycji składniowych, do wielosegmentowych wyrażeń o ustalonej postaci. L. Brinton wskazuje także na postępująca redukcję segmentów fonologicznych, czemu w języku polskim odpowiadałaby $\mathrm{m}$.in. tendencja do posługiwania się samym czasownikiem bez frazy zajmującej pozycję tematu wewnątrzzdaniowego czy też wybór postaci co // cokolwiek zamiast dopełniacza. Podobnie, w języku polskim można by mówić o desemantyzacji wyrażeń czasownikowych używanych w tych wyrażeniach: niezależnie od tego, czy posłużymy się czasownikiem powiedzieć, rzec, mówić, czy też sięgniemy po którąś z rzadszych możliwości, jak sadzić, myśleć, mamy te same dwa komponenty. Przypomnę: (a) wyodrębnienie rematu wypowiedzenia podstawowego i uczynienie zawartego w nim sadu $(p)$ tematem wypowiedzenia względnego, za pomoca którego (b) takiemu tematowi pojęciowemu przeciwstawiane sa inne, znane obu uczestnikom bieżącego aktu mowy, możliwe do wypowiedzenia sądy o przeciwnej treści $(\sim p)$. W interpretacji L. Brinton istota samego aktu mówienia czy też myślenia staje się w tych wyrażeniach kwestia drugorzędna, one same zaś przenoszą swój zakres odniesienia i oddziaływania $z$ poziomu zdania na poziom całego dyskursu, a jednym $z$ mechanizmów, który pośredniczy w tym procesie, jest ich użycie parentetyczne.

Odmienna interpretację dla języka angielskiego proponuje Christopher Potts [2002; 2005]. Jego zdaniem różne typy zdań i fraz apozytywnych to konstrukcje składniowe, których znaczenie jest pochodna zwiąanej z nimi implikatury konwencjonalnej. W tym ujęciu znaczenie opisane powyżej byłoby wynikiem implikatury konwencjonalnej, której działanie uwarunkowane jest użyciem określnego typu wyrażeń. Niewątpliwie ciekawe rezultaty mogłoby przynieść przyjrzenie się temu, czy i w jakim stopniu interpretacja C. Pottsa w odniesieniu do niektórych angielskich zdań i fraz apozytywnych czy też przysłówków dozdaniowych mogłaby znaleźć zastosowanie w interpretacji analogicznych polskich fraz i wyrażeń z zaimkami co // cokolwiek by nie oraz nieosobowymi formami podstawowych czasowników mówienia i myślenia.

Przedstawiona w tym artykule argumentacja bliższa jest stanowisku przyjętemu przez L. Brinton, choć z modyfikacja polegajaca na skupieniu się raczej na wyrażeniu cokolwiek by nie_ // co by nie,, niż na samych czasownikach mówić i powiedzieć jako regularnie wchodzacych w skład wielosegmentowych wyrażeń pełniących funkcję discourse markers, czyli wyrażeń metatekstowych. Analizowane przeze mnie wyrażenia należy albo uznać za zleksykalizowane (a ich czasownikowe uzupełnienia za zgramatykalizowane $\mathrm{w}$ tych konstrukcjach w rozumieniu L. Brinton, przedstawionym powyżej, w ramach szczególnego wypadku gramatykalizacji: procesu pragmatykalizacji), albo za takie, które znajdują się w końcowej fazie tego procesu (za czym $z$ kolei przemawiałyby kontrargumenty 
podane w artykule, w tym obecność wciąż jeszcze częstej rozbudowanej frazy wskazujacej na temat). Otwarta pozostaje kwestia tego, czy wyrażenia cokolwiek by nie_ // co by nie_ są we współczesnej polszczyźnie zjawiskiem izolowanym, czy też - jak sugerowałyby to częściowo rozważania w części poświęconej analizie dystrybucji - mają swój odpowiednik $\mathrm{w}$ parze gdzie nie_ i gdziekolwiek nie_ $z$ uzupełnieniami w postaci form nieosobowych czasowników spojrzeć, patrzeć, popatrzeć.

\section{Bibliografia}

A. Bogusławski, 1977, Problems of the Thematic-Rhematic Structure of Sentences, Warszawa.

A. Bogusławski, 1979, Performatives or metatextual comments? On the cognitive and non-cognitive linguistic conventions, „Kwartalnik Neofilologiczny” XXVI, z. 3, s. 301-326 (przedr. [w:] Sprawy słowa, Warszawa 1994).

A. Bogusławski, 1987, Obiekty języka a jednostki leksykograficzne [w:] Z. Saloni (red.), Studia z polskiej leksykografii współczesnej II, Białystok, s. 13-34.

A. Bogusławski, 1988, Preliminaria gramatyki operacyjnej, tłum. R. Gozdawa-Gołębiowski, „Polonica” XIII, s. 163-223. Oryginalne wydanie: A. Bogusławski, 1978, Towards an operational grammar, „Studia Semiotyczne” VIII, s. 29-90.

A. Bogusławski, 2008, O pewnym wykładniku równoważności lokucyjnej [w:] B. Wiemer, V.A. Plungjan (red.), Lexikalische Evidenzialitäts Marker in slavischen Sprachen, Monachium-Wiedeń, s. 67-93.

J. Bralczyk, 1978, O leksykalnych wyznacznikach prawdziwościowej oceny sadów, Katowice.

L. Brinton, 2008, The Comment Clause in English. Syntactic Origins and Pragmatic Development, Cambridge.

J. Chojak, 2009, Zrozumieć jak. Studium semantyczno-składniowe, Warszawa.

G. Cinque, 2008, Two types of non-restrictive relatives [w:] O. Bonami, P. Cabredo Hofherr (red.), Empirical Issues in Syntax and Semantic 7, Paryż, s. 99-137.

B. Citko, 2016, Types of appositive relative clauses in Polish, „Studies in Polish Linguistics" 11 (3), s. 85-85.

M. Danielewiczowa, 2018, Co powiem, kiedy powiem nie powiem. Przyczynek do opisu idiomatyki metatekstowej, „LingVaria” XIII, 2(26), s. 61-80.

L. Degand, A-M. Simon-Vandenbergen, 2011, Introduction: grammaticalization and (inter)subjectification of discourse markers, „Linguistics” 49 (2), s. 287-294.

M. Grochowski, 2000, Nieciagke jednostki jezyka z segmentem nie. Wybrane problemy składni zewnętrznej, wewnętrznej i leksykografii (tezy) [w:] M. Balowski, W. Chlebda (red.), Frazeografia słowiańska, Opole, s. 82-84.

ISJP: M. Bańko, 2000, Inny słownik języka polskiego, Warszawa.

S. Jodłowski, 1976, Podstawy składni polskiej, Warszawa.

R. Laskowski, 1991, Status gramatyczny wskaźnika syntaktycznego zespolenia $w$ zdaniach względnych $z$ co [w:] M. Grochowski, D. Weiss (red.), Words are Physicians for an Ailinig Mind, Monachium, s. 271-278.

J. Linde-Usiekniewicz, 2019, Polskie zdania względne $z$ wewnętrznym rzeczownikiem - wstępne rozpoznanie, „Poradnik Językowy” z. 9, s. 26-40. 
Z. Klemensiewicz, 1969, Zarys składni polskiej, Warszawa.

A. Moroz, 2010, Parenteza ze składnikiem czasownikowym we współczesnym języku polskim, Toruń.

K. Ożóg, 1990, Leksykon metatekstowy współczesnej polszczyzny mówionej. Wybrane zagadnienia, Kraków.

D. Piekarczyk, 2013, Metafory metatekstowe, Lublin.

K. Pisarkowa, 1984, Historia składni języka polskiego, Wrocław etc.

C. Potts, 2002, The lexical semantics of parentheticals -as and appositive-which, „Syntax” 5, s. 55-88.

C. Potts, 2005, The Logic of Conventional Implicature, Oxford.

SGPP: M. Grochowski, A. Kisiel, M. Żabowska, 2014, Słownik gniazdowy partykut polskich, Kraków.

M. Stępień, 2014, Wyrażenia parentetyczne $w$ strukturze wypowiedzi-właściwości semantyczne, składniowe, prozodyczne, Warszawa.

M. Stępień, 2018, Jak badać składnie wielosegmentowych wyrażeń metatekstowych? Na przykładzie wyrażeń (że)by nie $i$ że nie [w:] A. Dobaczewski, A. Moroz, P. Sobotka (red.), Sens i konwencje w języku. Studia dedykowane Profesorowi Maciejowi Grochowskiemu, Toruń, s. 325-344.

Z. Topolińska, 1967, Kategoria osoby w języku polskim, „Język Polski” XLVII, z. 2, s. 88-95.

Z. Topolińska, 1984, Składnia grupy imiennej [w:] Z. Topolińska (red.), Gramatyka współczesnego języka polskiego. Składnia, Warszawa, s. 301-389.

Z. Topolińska, 2001, Zdania wzgledne - forma czy funkcja, „Prace Filologiczne” 46, s. 597-604.

S. Urbańczyk, 1939, Zdania rozpoczynane wyrazem co w języku polskim, Kraków.

USJP: S. Dubisz (red. nauk.), 2003, Uniwersalny słownik języka polskiego, Warszawa.

J. Wajszczuk, 1997, System znaczeń w obszarze spójników polskich. Wprowadzenie do opisu, Warszawa.

J. Wajszczuk, 2005, O metatekście, Warszawa.

WSPP: A. Markowski (red.), 2004, Wielki słownik poprawnej polszczyzny, Warszawa.

Z. Zaron, 2009, Problemy składni funkcjonalnej, Warszawa.

L. Zawadowski, 1952, Zagadnienia teorii zdań względnych, Wrocław.

Źródła przykładów

KDP: Korpus Dyskursu Parlamentarnego: https://kdp.nlp.ipipan.waw.pl/ query_text/

M. Ogrodniczuk, 2018, Polish Parliamentary Corpus [w:] D. Fišer, M. Eskevich, F. de Jong (red.), Proceedings of the LREC 2018 workshop ParlaCLARIN: creating and using parliamentary corpora, Paryż, s. 15-19.

NKJP-PELCRA: Narodowy Korpus Języka Polskiego: www.nkjp.pl za pośrednictwem wyszukiwarki PELCRA

A. Przepiórkowski, M. Bańko, R.G. Górski, B. Lewandowska-Tomaszczyk, 2012, Narodowy Korpus Języka Polskiego, Warszawa.

SPOKES - Conversational Corpus DATA: P. Pęzik, 2015, Spokes - a search and exploration service for conversational corpus data [w]: Selected papers from the CLARIN 2014 conference, October 24-25, 2014, Soesterberg, s. 99-109. 


\section{Lexicalisation of developing clauses with expressions cokolwiek and co (whatever) functioning as a metatextual commentary}

Summary

The aim of this paper is to demonstrate the lexicalisation and pragmaticalisation process, as a result of which - in modern Polish - developing clauses, also called non-integrated appositive relative clauses, give rise to metatextual expressions, which comment on a statement/utterance (discourse markers) in the form co by nie / cokolwiek by nie (whatever you) with supplementations in the form of infinitives mówić, powiedzieć, rzec (say). The expressions were subject to an analysis intended to determine their distribution, form and connectivity, as well as semantic and syntactic properties, including functions in the thematicrhematic structure. The discussions allowed also for the possibility to interpret the described phenomenon in the categories of conventional implicature.

Keywords: metatextual expressions (discourse markers) - relative clauses - developing clauses - verbs of speaking (mówić, rzec, powiedzieć (say)) - relative pronouns (co, cokolwiek (whatever)) - thematic-rhematic structure (topic-focus articulation)

Trans. Monika Czarnecka 